\title{
Field host range of the fire ant pathogens Thelohania solenopsae (Microsporida: Thelohaniidae) and Vairimorpha invictae (Microsporida: Burenellidae) in South America
}

\author{
Juan A. Briano, ${ }^{a, *}$ D.F. Williams, ${ }^{b}$ D.H. Oi, ${ }^{b}$ and L.R. Davis Jr. ${ }^{b}$ \\ ${ }^{a}$ USDA-ARS South American Biological Control Laboratory, Bolivar 1559 (1686) Hurlingham, Buenos Aires Province, Argentina \\ ${ }^{\mathrm{b}}$ USDA-ARS Center for Medical, Agricultural, and Veterinary Entomology, P.O. Box 14565, Gainesville, FL 32604, USA
}

Received 17 July 2001; accepted 4 December 2001

\begin{abstract}
We studied the field host specificity of the microsporidia Thelohania solenopsae and Vairimorpha invictae and their prevalence in the imported fire ants, Solenopsis invicta and S. richteri. Terrestrial ants were sampled by using bait traps and/or nest sampling at preselected sites in Argentina and Brazil. The sampling included the genera Solenopsis, Pheidole, Camponotus, Crematogaster, Linepithema, Brachymyrmex, Paratrechina, Dorymyrmex, and Wasmannia. The samples were examined under a phase-contrast microscope for the presence of microsporidian infections. The bait trap sampling revealed that: (1) T. solenopsae infected only S. richteri, $S$. invicta, and Solenopsis sp. at 6-67\% of the sites and in $1.5-29 \%$ of the traps; (2) V. invictae infected only $S$. invicta at $6 \%$ of the sites and in $3 \%$ of the samples. The nest sampling revealed that: (1) $T$. solenopsae infected $S$. invicta, S. richteri, and S. macdonaghi, at $41-67 \%$ of the sites and in $11-58 \%$ of the colonies; (2) $V$. invictae infected the same species at $15-50 \%$ of the sites and in $2-26 \%$ of the colonies. We detected $T$. solenopsae and $V$. invictae in equal percentages of $S$. invicta sites (41\%); however, the percentage of colonies infected with $V$. invictae was $20 \%$ and with $T$. solenopsae only $11 \%$. At $S$. richteri sites, in contrast, T. solenopsae occurred at $46 \%$ of the sites and $15 \%$ of the colonies and $V$. invictae occurred at only $15 \%$ of the sites and $2 \%$ of the colonies. In S. macdonaghi, T. solenopsae was detected at $67 \%$ of the sites and $58 \%$ of the colonies, and $V$. invictae was detected at $50 \%$ of the sites and $26 \%$ of the colonies. This is the first report of $V$. invictae infecting $S$. macdonaghi. The proportion of $S$. richteri and $S$. invicta infected with $T$. solenopsae was similar. In contrast, the proportion of $S$. invicta infected with $V$. invictae was higher than $S$. richteri. We conclude that the microsporidia, $T$. solenopsae and $V$. invictae, show a very high specificity for Solenopsis ants in the field. It appears that $T$. solenopsae infects $S$. invicta and $S$. richteri equally but $V$. invictae may be more adapted to infect S. invicta. Published by Elsevier Science (USA).
\end{abstract}

Keywords: Thelohania solenopsae; Vairimorpha invictae; Solenopsis invicta; S. richteri; Host specificity; Imported fire ants

\section{Introduction}

The microsporidia, Thelohania solenopsae Knell, Allen, and Hazard (Microsporida: Thelohaniidae) and Vairimorpha invictae Jouvenaz and Ellis (Microsporida: Burenellidae), are pathogens associated with fire ants, Solenopsis spp., in South America. The former was also discovered recently in the southern United States infecting the red imported fire ant, Solenopsis invicta

\footnotetext{
${ }^{*}$ Corresponding author. Fax: +54-11-4452-4838.

E-mail address: jabriano@mail.retina.ar (J.A. Briano).
}

Buren, (Williams et al., 1998) and is being evaluated as a biological control agent for fire ants.

According to Tanada and Kaya (1993), the microsporidia, as a group, are the most promising protozoalike microorganisms for use as microbial control agents. They are obligate, intracellular pathogens that produce acute or chronic infections in insects. Both $T$. solenopsae and $V$. invictae are dimorphic and produce meiospores and free spores that develop in adult fire ant workers, sexuals, and queens and, in the case of $V$. invictae, also in pupae and larvae (Briano et al., 1996; Jouvenaz and Ellis, 1986; Knell et al., 1977; J.A.B., unpublished information). 
Surveys of these microsporidia infecting fire ants have been conducted in South America since the 1970s and infections have been reported in $S$. invicta, S. richteri Forel, S. saevissima Smith, S. quinquecuspis Forel, S. macdonaghi Santschi, and S. blumi Buren (Allen and Buren, 1974; Allen and Knell, 1980; Allen and Silveira Guido, 1974; Briano et al., 1995; Jouvenaz, 1983, 1986, 1990; Jouvenaz et al., 1980; Williams and Whitcomb, 1974; Wojcik et al., 1987). T. solenopsae is the most common fire ant pathogen in South America. In some areas of Buenos Aires Province, Argentina, it infects from 40 to $80 \%$ of the fire ants (Briano et al., 1995). Much less is known about $V$. invictae field infection rates. Records of field hosts for $V$. invictae are restricted to $S$. invicta [Jouvenaz et al., 1980 (as "undescribed microsporidium"); Jouvenaz and Ellis, 1986; Wojcik et al., 1987] and S. richteri (Briano et al., 1995). In addition, the presence of these two pathogens in non-fire ant species has never been determined. The study of the field host range of $T$. solenopsae and $V$. invictae in their aboriginal area will help to predict their ecological host range in a new habitat. The objectives of this study were to determine the field host specificity (ecological host range) of $T$. solenopsae and $V$. invictae and to determine any difference in susceptibility of the imported fire ants, $S$. invicta and $S$. richteri, to the two microsporidian species.

\section{Materials and methods}

We conducted the study during 1993 (November and December, spring), 1994 (February-May, summer-fall), 1998 (October and November, spring), 1999 (April, July, August and November, fall-winter-spring), and 2000 (February, May, and October, summer-fall-spring). We sampled terrestrial ants that occurred sympatrically with fire ants infected with $T$. solenopsae and/or $V$. invictae, at 1-6 sites within each of several areas of the provinces of Buenos Aires, Santa Fe, Chaco, Corrientes, and Entre Rios, Argentina, and the state of Mato Grosso, Brazil. Ants were sampled using one or both of the following two approaches: (1) bait trap sampling and (2) nest sampling.

\subsection{Bait trap sampling}

Bait traps were used at 52 preselected roadside sites within the areas of Pergamino, Bragado, Saladillo, Navarro, Mercedes, Moreno, Solís, Pilar, and Escobar (Buenos Aires Province), Timbúes, Recreo, San Justo, Gobernador Crespo, Vera y Pintado, Calchaquí, Cello, Vera, Malabrigo, and Berna (Santa Fe Province). Sites that previously had $T$. solenopsae and/or $V$. invictae infecting fire ants were selected for sampling (Briano et al., 1995; J.A.B., unpublished data). Our sampling methods were similar to those reported by Porter et al. (1997). At each site, 10 bait stations consisting of a disposable 7-ml glass vial containing a small piece of canned "Vienna" sausage were established. Depending on the air temperature, the vial traps were left on the ground surface for 30-60 min. In most cases, the traps were shaded with a $15-\mathrm{cm}$ plastic plate to keep traps cooler. The ants trapped, usually ranging from 50 to 400 specimens/trap, were preserved in $70 \%$ ethanol and transported to the laboratory for examination.

\subsection{Nest sampling}

This sampling complemented the bait traps and was primarily used to sample as many nests as possible of $S$. invicta and $S$. richteri. The purpose was to assess a differential susceptibility, if any, of the fire ant species to $T$. solenopsae and $V$. invictae. When detected, nests of other ant species were also sampled.

The sampling consisted of visually searching for ant nests and was conducted in 90 sites in Argentina and Brazil. In Argentina, we collected at the 52 sites used for bait trapping and in other areas such as Las Flores (Buenos Aires), Basail, Resistencia (Chaco), Corrientes, San Roque, Goya, Esquina (Corrientes), La Paz, Paraná, Victoria, and Gualeguay (Entre Rios). Most of these areas were selected systematically every $10-100 \mathrm{~km}$ along the main highways on both sides of the Paraná River during an exploratory trip to Northern Argentina. In Brazil, we sampled at four sites within the areas of Cuiaba, the type locality of both microsporidia, and Cáceres (Mato Grosso). A total of 585 ant colonies were sampled by inserting a 7-ml disposable glass vial (coated with talc) into each nest for a few minutes. The samples, containing approximately 200-3000 worker ants, were preserved in $70 \%$ ethanol and transported to the laboratory for examination.

\subsection{Disease diagnosis}

Alcohol-preserved samples $(n=928)$ obtained by the two methods described above were macerated individually in water with a tissue grinder (Tekmar SDT Tissumizer) and a drop of the aqueous extract was examined under a phase-contrast microscope $(400 \times)$ for the presence of spores of $T$. solenopsae and/or $V$. invictae. The sensitivity of this procedure was successfully tested by Jouvenaz et al. (1977). Both meiospores and free spores of these two microsporidia are clearly distinctive in size and were easily detected when present in the samples. A few ant specimens were not macerated and were used for taxonomic identification. Most ant species were identified with available keys (Bolton, 1994, 1995; Gonçalves, 1961; Kusnezov, 1978). Gas chromatography analysis (Vander Meer and Lofgren, 1990) was used to confirm the identification of some samples of fire ants. Voucher 
specimens were deposited at the USDA-ARS-South American Biological Control Laboratory in Hurlingham, Argentina and at the USDA-ARS-Center for Medical, Agricultural and Veterinary Entomology, in Gainesville, FL.

\subsection{Statistical analysis}

Chi-square tests (Minitab Statistical Software, 1991) were used to compare the prevalence of $T$. solenopsae and $V$. invictae in $S$. invicta and $S$. richteri. Other Solenopsis species were not considered in the analysis because of sample size limitations.

\section{Results and discussion}

\subsection{Bait trap sampling}

Nine ant genera in the subfamilies Myrmicinae, Formicinae, and Dolichoderinae, and some undetermined ants were detected in the bait traps (Table 1). S. richteri, S. invicta, Pheidole spp., Camponotus spp., and Crematogaster sp. were the most abundant ants collected in traps and were present at a minimum of 10 sites. Other ants trapped were Linepithema sp., Pheidole radoszkowskii Mayr, Solenopsis sp., Brachymyrmex sp., Paratrechina pubens (Forel), Dorymyrmex spp., and Wasmannia auropunctata (Roger) (Table 1).

Thelohania solenopsae infected only ants in the genus Solenopsis (Table 1). This microsporidium was found at $64 \%$ of the sites and in $29 \%$ of the traps with $S$. richteri, at $25 \%$ of the sites and in $20 \%$ of the traps with Solenopsis sp., and at $6 \%$ of the sites and $1.5 \%$ of the traps with $S$. invicta. However, only four sites and five traps contained Solenopsis sp.
Vairimorpha invictae occurred only in S. invicta at $6 \%$ of the sites and in 3\% of the samples. The presence of this pathogen in trapped fire ants was low including those sites where it had been detected in relatively high prevalence in previous surveys (J.A.B., unpublished data). Also, it was low or even absent in sites where the presence of $V$. invictae was later confirmed through the nest sampling and examination of fire ant nests. The reason for this remains unclear. One possible explanation is that fire ant workers infected with $V$. invictae drastically reduce foraging activity and, consequently, were not trapped. This needs further investigation but some laboratory observations (J.A.B., unpublished data) revealed that colonies with $V$. invictae showed rapid mortality of infected workers which may affect the foraging capability of the colonies.

The distribution of ant species was wide. Ants were found at 51 of the 52 sites surveyed. However, the abundance of ants was low; a high proportion (177/ $520=34 \%$ ) of traps were found empty. In addition, some ant species such as Linepithema sp., P. radoszkowskii, Solenopsis sp., Brachymyrmex sp., P. pubens, Dorymyrmex spp., and $W$. auropunctata occurred in insufficient numbers to allow certainty of disease presence. However, we detected infection of $T$. solenopsae in Solenopsis sp. that occurred at $8 \%(4 / 52)$ of the sites and in $1 \%(5 / 520)$ of the traps (Table 1$)$.

\subsection{Nest sampling}

Nests of S. richteri, S. invicta, S. macdonaghi, Acromyrmex sp., A. lundi (Guerin-Meneville), A. ambiguus (Emery), Pheidole sp., and Camponotus sp. were found (Table 2). Solenopsis invicta and Acromyrmex spp. occurred at the greatest number of sites but the most abundant species were $S$. richteri and $S$. invicta.

Table 1

Field host range of Thelohania solenopsae and Vairimorpha invictae: bait trap sampling

\begin{tabular}{|c|c|c|c|c|c|c|}
\hline \multirow[t]{2}{*}{ Ants trapped } & \multicolumn{3}{|c|}{ No. $(\%)$ of sampling sites per species ${ }^{\mathrm{a}}$} & \multicolumn{3}{|c|}{ No. $(\%)$ of traps per species ${ }^{b}$} \\
\hline & Total & With $T$. solenopsae & With $V$. invictae & Total & With $T$. solenopsae & With $V$. invictae \\
\hline Solenopsis richteri & 22 & $14(64)$ & 0 & 75 & $22(29)$ & 0 \\
\hline Pheidole spp. & 25 & 0 & 0 & 57 & 0 & 0 \\
\hline Camponotus spp. & 19 & 0 & 0 & 46 & 0 & 0 \\
\hline Crematogaster sp. & 10 & 0 & 0 & 28 & 0 & 0 \\
\hline Solenopsis sp. & 4 & $1(25)$ & 0 & 5 & $1(20)$ & 0 \\
\hline Brachymyrmex sp. & 2 & 0 & 0 & 2 & 0 & 0 \\
\hline Paratrechina pubens & 2 & 0 & 0 & 2 & 0 & 0 \\
\hline Dorymyrmex spp. & 2 & 0 & 0 & 2 & 0 & 0 \\
\hline Wasmannia auropunctata & 1 & 0 & 0 & 1 & 0 & 0 \\
\hline Other spp. & 6 & 0 & 0 & 10 & 0 & 0 \\
\hline
\end{tabular}

\footnotetext{
${ }^{\mathrm{a}}$ Total sites $=52$.

${ }^{\mathrm{b}}$ Total traps $=520$.
} 
Table 2

Field host range of Thelohania solenopsae and Vairimorpha invictae: nest sampling

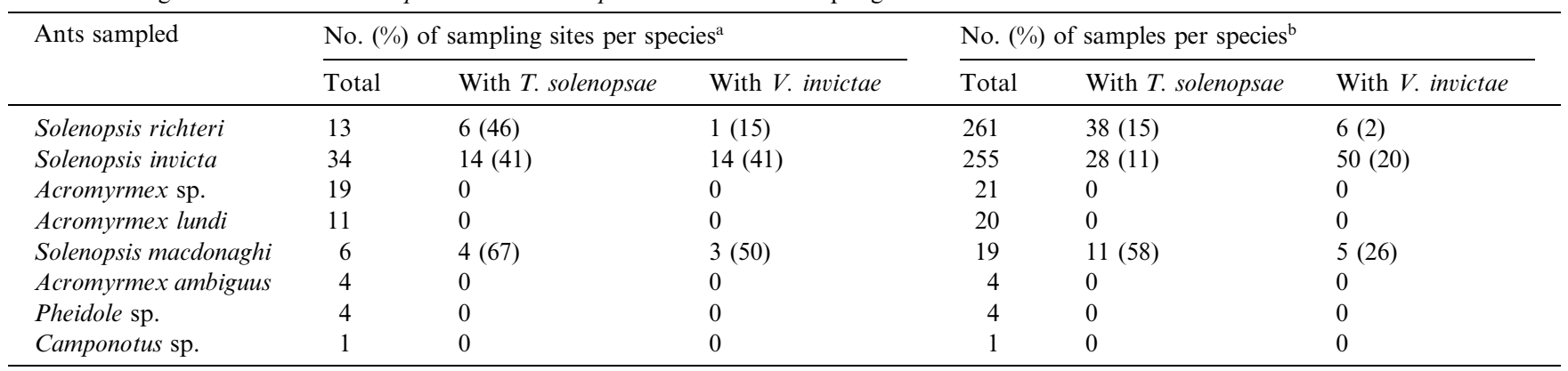

${ }^{\text {a }}$ Total sites $=90$

${ }^{\mathrm{b}}$ Total samples (colonies) $=585$.

$T$. solenopsae only infected $S$. invicta, $S$. richteri, and S. macdonaghi, at $41-67 \%$ of the sites and in $11-58 \%$ of the colonies examined. In addition, $V$. invictae infected the same hosts at $15-50 \%$ of the sites and in $2-26 \%$ of the colonies examined (Table 2).

At $S$. invicta sites, $T$. solenopsae and $V$. invictae occurred in the same percentage (41\%). However, the percentage of $S$. invicta colonies infected with $V$. invictae was $20 \%$ and with $T$. solenopsae only $11 \%$ (Table 2 ). In contrast, at $S$. richteri sites, $T$. solenopsae occurred at $46 \%$ of the sites and $V$. invictae only at $15 \%$ of the sites. T. solenopsae infected $15 \%$ of the S. richteri colonies and $V$. invictae only $2 \%$. In regards to $S$. macdonaghi, T. solenopsae occurred at $67 \%$ of the sites and infected $58 \%$ of the colonies, and $V$. invictae occurred at $50 \%$ of the sites and infected $26 \%$ of the colonies, but the sample size was limited to six sites and 19 colonies. The percentages are not comparable with those found in $S$. invicta and $S$. richteri. That is, the proportion of $S$. richteri and $S$. invicta sites with $T$. solenopsae was similar $(46 \%$ and $41 \%$, respectively; $\chi^{2}=0.095 ; d f=1 ; P>0.1$. The proportion of $S$. richteri and $S$. invicta colonies infected with $T$. solenopsae was similar (15 and $11 \%$, respectively; $\left.\chi^{2}=1.481 ; d f=1 ; P>0.1\right)$. In contrast, the proportion of $S$. invicta sites with $V$. invictae was higher than $S$. richteri sites (41 versus $15 \% ; \chi^{2}=4.852 ; d f=1$; $P<0.05$ ). Also, the proportion $S$. invicta colonies infected with $V$. invictae was higher than $S$. richteri colonies (20 versus $2 \% ; \chi^{2}=39.942 ; d f=1 ; P<0.005$ ). These data suggest a possible differential susceptibility of $S$. invicta to $V$. invictae and should be confirmed with appropriate laboratory tests. These tests should be conducted when the mechanisms of transmission of $V$. invictae are known.

The information reported here regarding $T$. solenopsae is consistent with the surveys conducted in South America by Allen and Buren (1974), Allen and Silveira Guido (1974), Allen and Knell (1980), Jouvenaz (1983), Jouvenaz et al. (1980), Wojcik et al. (1987), and Briano et al. (1995), where they found T. solenopsae infecting colonies of $S$. invicta, S. richteri, S. saevissima, S. quinquecuspis,
S. macdonaghi, and S. blumi. In the United States, infections of $T$. solenopsae have not been detected in fieldcollected S. geminata (Fabricius) (Williams et al., 1998) and S. xyloni (MacCook) (D.H.O., unpublished data). In addition, this microsporidium was not detected in other ants species in the genera Dorymyrmex, Pheidole, Camponotus, Trachymyrmex, and Brachymyrmex (Williams et al., 1998). Records of field hosts for $V$. invictae are restricted to $S$. invicta (Jouvenaz and Ellis, 1986; Jouvenaz et al., 1980; Wojcik et al., 1987) and $S$. richteri (Briano et al., 1995). This is the first report of $V$. invictae infecting field colonies of S. macdonaghi.

These results strongly suggest that the host ranges of $T$. solenopsae and $V$. invictae are restricted to closely related species within the genus Solenopsis. It appears that $T$. solenopsae infects $S$. invicta and $S$. richteri equally but $V$. invictae may be more adapted to infect S. invicta.

\section{Acknowledgments}

We thank Roberto Pereira and Jerry Hogsette (USDA-ARS-CMAVE, Gainesville, FL) for the valuable suggestions to improve the manuscript. Also, Bob Vander Meer (USDA-ARS-CMAVE, Gainesville, FL) for his help with the fire ant identifications using gas chromatography.

\section{References}

Allen, G.E., Buren, W.F., 1974. Microsporidian and fungal diseases of S. invicta Buren in Brazil. J. NY Entomol. Soc. 82, 125-130.

Allen, G.E., Knell, J.D., 1980. Pathogens associated with the Solenopsis saevissima complex in South America. Proc. Annu. Tall Timbers Conf. Ecol. Animal Control Habitat Manage. 7, 87-94.

Allen, G.E., Silveira Guido, A., 1974. Occurrence of microsporidia in Solenopsis richteri and Solenopsis sp. in Uruguay and Argentina. Fla. Entomol. 57, 327-329.

Bolton, B., 1994. Identification Guide to the Ant Genera of the World. Harvard University Press, Cambridge, MA.

Bolton, B., 1995. A New General Catalogue of the Ants of the World. Harvard University Press, Cambridge, MA. 
Briano, J.A., Jouvenaz, D.P., Wojcik, D.P., Cordo, H.A., Patterson, R.S., 1995. Protozoan and fungal diseases in Solenopsis richteri and S. quinquecuspis (Hymenoptera: Formicidae), in Buenos Aires province, Argentina. Fla. Entomol. 78, 531-537.

Briano, J.A., Patterson, R.S., Becnel, J.J., Cordo, H.A., 1996. The black imported fire ant, Solenopsis richteri, infected with Thelohania solenopsae: intracolonial prevalence and evidence for transovarial transmission. J. Invertebr. Pathol. 67, 178-179.

Gonçalves, C.R., 1961. O genero Acromyrmex no Brasil (Hym. Formicidae). Stud. Entomol. 4, 113-180.

Jouvenaz, D.P., 1983. Natural enemies of fire ants. Fla. Entomol. 66, $111-121$

Jouvenaz, D.P., 1986. Diseases of fire ants: problems and opportunities. In: Lofgren, C.S., Vander Meer, R.K. (Eds.), Fire Ants and Leaf-Cutting Ants: Biology and Management. Westview Press, Boulder, CO, pp. 327-338.

Jouvenaz, D.P., 1990. Approaches to biological control of fire ants in the United States. In: Vander Meer, R.K., Jaffe, K., Cedeño, A. (Eds.), Applied Myrmecology: A World Perspective. Westview, Boulder, CO, pp. 620-627.

Jouvenaz, D.P., Ellis, E.A., 1986. Vairimorpha invictae n. sp. (Microspora: Microsporida), a parasite of the red imported fire ant, Solenopsis invicta Buren (Hymenoptera: Formicidae). J. Protozool. 33, 457-461.

Jouvenaz, D.P., Allen, G.E., Banks, W.A., Wojcik, D.P., 1977. A survey for pathogens of fire ants, Solenopsis spp., in the southern United States. Fla. Entomol. 60, 275-279.

Jouvenaz, D.P., Banks, W.A., Atwood, J.D., 1980. Incidence of pathogens in fire ants, Solenopsis spp., in Brazil. Fla. Entomol. 63, 345-346.
Knell, J.D., Allen, G.E., Hazard, E.I., 1977. Light and electron microscope study of Thelohania solenopsae n. sp. (Microsporida: Protozoa) in the red imported fire ant, Solenopsis invicta. J. Invertebr. Pathol. 29, 192-200.

Kusnezov, N., 1978. Hormigas Argentinas: Clave para su Identificación. Ministerio de Cultura y Educación, Fundación Miguel Lillo, Tucumán.

Minitab Statistical Software. 1991. Reference manual, release 8. Minitab, State College, PA.

Porter, S.D., Williams, D.F., Patterson, R.S., Fowler, H.G., 1997. Intercontinental differences in the abundance of Solenopsis fire ants (Hymenoptera: Formicidae): escape from natural enemies? Environ. Entomol. 26, 373-384.

Tanada, Y., Kaya, H.K., 1993. Insect Pathology. Academic Press, San Diego, CA.

Vander Meer, R.K., Lofgren, C.S., 1990. Chemotaxonomy applied to fire ant systematics in the United States and South America. In: Vander Meer, R.K., Jaffe, K., Cedeño, A. (Eds.), Applied Myrmecology: A World Perspective. Westview, Boulder, CO, pp. 75-84.

Williams, D.F., Knue, G.J., Becnel, J.J., 1998. Discovery of Thelohania solenopsae from the red imported fire ant, Solenopsis invicta, in the United States. J. Invertebr. Pathol. 71, 175-176.

Williams, R.N., Whitcomb, W.H., 1974. Parasites of fire ants in South America.Proc. Annu. Tall Timbers Conf. Ecol. Animal Control Habitat Manage. 5, 49-59.

Wojcik, D.P., Jouvenaz, D.P., Banks, W.A., Pereira, A.C., 1987. Biological control agents of fire ants in Brazil. In: Eden, J., Rembold, H. (Eds.), Chemistry and Biology of Social Insects. Verlag, Munich, pp. 627-628. 